\title{
RARITY AND LIMITED GEOGRAPHICAL COVERAGE OF INDIVIDUAL LEVEL ALCOHOL INTERVENTIONS IN SUB SAHARAN AFRICA. FINDINGS FROM A SCOPING REVIEW.
}

\section{Authors:}

Joel M Francis ${ }^{1,2, * \pi}$, Sarah Cook ${ }^{3 \rrbracket}$, Neo K Morojele ${ }^{5,6,7 ¥}$, Monica H Swahn ${ }^{4 ¥}$

Email: JMF: joelmfrancis@gmail.com;SC: sarah.cook@Ishtm.ac.uk; MHS:

mswahn@gsu.edu ; NKM: neo.morojele@mrc.ac.za

${ }^{1}$ WITS Reproductive Health \& HIV Institute (WRHI), School of Clinical Medicine, Faculty of Health Sciences, University of the Witwatersrand, Johannesburg, South Africa

${ }^{2}$ Department of Epidemiology and Biostatistics, Muhimbili University of Health and Allied Sciences, Dar es Salaam, Tanzania

${ }^{3}$ Faculty of Epidemiology and Population Health, London School of Hygiene \& Tropical Medicine, London, United Kingdom

${ }^{4}$ Department of Population Health Sciences, School of Public Health, Georgia State University, Atlanta, USA

${ }^{5}$ Alcohol, Tobacco \& Other Drug Research Unit, South African Medical Research Council, Pretoria, South Africa

${ }^{6}$ School of Public Health and Family Medicine, University of Cape Town, Cape Town, South Africa

${ }^{7}$ School of Public Health, University of the Witwatersrand, Johannesburg, South Africa

*Corresponding author: joelmfrancis@gmail.com

"Equal contribution

${ }^{\sharp}$ Equal contribution 


\section{Abstract}

Introduction

A previous review on brief alcohol interventions in sub-Sahara Africa showed most of the interventions were implemented in East and Southern Africa. We carried a scoping review to assess the current amount and types of alcohol interventions in SSA.

\section{Methods}

We searched six databases (MEDLINE, EMBASE, Global Health, Africa-wide, CINAHL and PsycINFO) for publications prior to June 2018. We used the search terms for alcohol use, alcohol intervention and African countries' names. We identified 59 papers on alcohol interventions of which 26 were eligible for inclusion in the final analysis.

\section{Results}

Of the 26 eligible papers, $18(69 \%)$ were carried out in South Africa. Majority 15(58\%) of the interventions were randomized clinical trial, followed by seven (27\%) quasi-experimental and evaluation of the intervention and five (19\%) cluster randomized trials. Most of the studies targeted patients and pregnant women. Only a few studies focused on sex workers and students.

\section{Conclusions}

Our findings show that the assessment of effectiveness of individual level alcohol interventions is rare in SSA. In addition, these interventions were polarised in two countries. There is an urgent need for an evidence base on the effectiveness of alcohol interventions commensurate with the scope of the problem in SSA. 
Keywords: Alcohol use; Interventions; Review; Africa, Word count= 200

\section{Main Text}

\section{Introduction}

Harmful alcohol use is a major public health problem worldwide. The WHO reports that globally, 2.3 billion people are current drinkers, and alcohol use is responsible for $5.3 \%$ of all deaths and $5.1 \%$ of the burden of disease in disability adjusted life years (DALYs) globally (Rehm et al., 2009). The total adult per capita consumption among adults in 2016 in the World Health Organisation (WHO) African region was 6.3 Litres of pure ethanol (World 6.4 Litres). While this is an intermediate level behind the European, West pacific and American regions, there are high overall levels of abstention within the African region (World Health Organisation, 2018). The per capita use limited to drinkers, indicated a much higher level of use, 18.4 litres, (world 15.1 Litres) demonstrating a substantial risk from alcohol among those who drink (World Health Organisation, 2018). However, there are also several other factors related to alcohol use that are not necessarily unique to Africa but that exacerbate the issue of alcohol use and harm. For example, use of unrecorded alcohol, which by definition is difficult to measure, is also expected to be very high in some areas of the African region. As such, any official estimates of alcohol use are considered significant underestimates of the true consumption (World Health Organisation, 2018). Moreover, there is substantial variation in levels of alcohol consumption within the WHO African region and in several countries alcohol consumption is reportedly increasing (World Health Organisation, 2018). A systematic review of alcohol use among young people in eastern Africa found that alcohol use was common, particularly among certain population groups, suggesting that the prevalence of 
alcohol use is increasing (Francis, Grosskurth, Changalucha, Kapiga, \& Weiss, 2014). Of particular concern within many countries in Africa is the aggressive advertisement of alcohol particularly to youth (Letsela, Weiner, Gafos, \& Fritz, 2018; Morojele et al., 2018) , increased availability because of limited enforcement of the minimum legal drinking age of 18 in most countries, and easy access because few countries have restrictions and licensing for alcohol sales (Ferreira-Borges, Esser, Dias, Babor, \& Parry, 2015). These are all factors that may exacerbate the current situation and significantly increase the prevalence and incidence of alcohol misuse across the African region (Francis et al., 2015). As such, there is a clear need to strengthen alcohol policies and control and capacity building at the country level in the African region (Ferreira-Borges et al., 2015).

An effective public health response to hazardous levels of alcohol consumption requires a strong evidence base on alcohol interventions. Alcohol interventions are needed at both the population and the individual level - for example, interventions related to alcohol policy (e.g., advertising, price, and availability) and at the clinical level (e.g. motivational interviewing for people with alcohol use disorders) - as both approaches have a role in reducing harm from alcohol use. In order to assess the current state and readiness to address the growing public health concern of alcohol misuse and to plan for the future it is critically important to determine what types of interventions have been implemented and evaluated in SSA. A previous review on brief alcohol interventions (published papers by the end of 2009) in subSahara Africa showed most of the interventions were implemented in East and Southern Africa (Karl Peltzer, 2014). The aim of this scoping review was to map past and ongoing alcohol interventions regardless of their efficacy/effectiveness within SSA to inform the ministries of health, investigators and stakeholders on the state of the existing evidence base on alcohol interventions in SSA. . 


\section{Methods}

We used a two-step process in identifying and reviewing alcohol interventions in SSA. First, we systematically searched the databases for published manuscripts and protocols regarding alcohol interventions within SSA. Second, we contacted experts, investigators and researchers who are working in the alcohol field through (step two) relevant internet forums: African Networks for Health Research and Development (AFRO-NETS), Health Information for All (HIFA), Kettil Bruun Society-“KBS” and the International Network on Brief Interventions for Alcohol and Other Drugs (Inebria). We requested that investigators share information on their past and current alcohol interventions (appendix-1).

\section{Search strategy}

We searched six databases (MEDLINE, EMBASE, Global Health, Africa-wide, CINAHL and PsycINFO) for publications prior to June 2018. We used the search terms for alcohol use, alcohol intervention and sub-Saharan African countries' names (appendix -2).We combined the alcohol use AND intervention and sub-Saharan African countries search terms. Two authors (JMF and SC) conducted the search independently. Titles and abstracts of all records identified were screened by JMF. Only individual level alcohol interventions conducted (completed or protocols) in 48 countries in sub-Saharan Africa were eligible for inclusion. We used the preferred reporting items for systematic reviews and meta-analyses (PRISMA) extension for scoping reviews guidelines (Tricco et al., 2018).

Data extraction 
We used a data extraction form to collect the following information from each eligible paper: i) author(s); ii) year the study was conducted; iii) year of publication; iv) study design; v) sample size; vi) country; vii) targeted population; viii) study settings; ix) alcohol intervention/s; x) maximum follow-up time and xi) primary alcohol outcome/s.

\section{Statistical analysis}

In this scoping review, we computed the proportion of the general characteristic of the following variables: countries, type of interventions, study designs employed, targeted populations and the primary outcome(s) of the interventions. We excluded non-intervention studies.

\section{Results}

Identified papers

We had very few responses $(n=9)$ from the online forums and all of the reported interventions obtained from these forums were also captured in the published studies which were part of the systematic search. For ease of reporting, our results focus only on the findings as described in the papers based on the systematic search and review of the published literature. The process for identifying and selecting interventions to be reviewed are outlined in Figure 1. The review yielded 6,415 citations, out of which 2,598 (40\%) were duplicates. One investigator shared one citation of an intervention. We screened 3,818 citations and identified 59 citations for full article review. After a full review, we excluded 33 articles, as these were interventions carried out in other parts of the world. The analyses are based on the 26 articles (published interventions and protocols) remaining. One study, which entailed 
a multi-country study, included samples from both Zimbabwe and Kenya. Table 1 describes the main review results as follows:

Countries that implemented the interventions

Most of the studies were conducted in South Africa $(n=19)$, followed by Kenya $(n=4)$ and Uganda $(n=2)$. One study had been conducted in each of the following countries: Nigeria, Rwanda and Zimbabwe.

Time of the intervention implementation

In this report, the earliest intervention noted, conducted in 1996, was a multinational study conducted by the World Health Organisation(WHO BriefIntervention Study Group, 1996). Most studies ( $n=14)$ were completed from 2010 onwards, 5 were completed before 2010, while the date on which the study was conducted (and completed) was not reported in eight cases.

Interventions settings

The intervention settings were mainly health care settings $(n=12)$, followed by communities $(n=7)$, both health care settings and communities $(n=4)$, drinking venues $(n=1)$, a university $(n=1)$ and a health facility and the local media $(n=1)$.

\section{Target populations}

In terms of the target population for the interventions, most $(n=8)$ were patients, particularly those living with HIV $(n=4)$. While the remainder consisted of health care providers $(n=3)$, members of the general population $(n=3)$, family members/care givers of HIV-infected patients $(n=1)$, pregnant women $(n=4)$, employees $(n=1)$, university students $(n=1)$, unemployed men $(n=1)$, men in the general population $(n=1)$, and female sex workers $(n=1)$. 
Interventions designs

The most frequently noted intervention design were randomized clinical trials $(n=13)$ followed by quasi-experimental $(n=3)$, and finally cluster randomized trials $(n=6)$, while four papers described the design as "evaluation of the intervention" or "evaluation of the program" $(n=4)$.

Types of the interventions

The intervention types were mostly alcohol screening and brief intervention $(n=17)$, followed by motivational interviewing approach and the remaining involved training of providers $(n=3)$ on how to deliver alcohol interventions and interventions focusing on health education.

\section{Duration of the interventions}

While the primary outcomes varied across intervention, most were related to some form of alcohol use reduction and the maximum follow-up time ranged from 8 weeks to 3 years. Three studies had a brief follow-up period of less than six months, with nine studies having a 6month or 24-week follow-up period, three having a 9-month follow-up period, six having a 12-month follow-up period, and four studies having a follow-up period that was longer than 12 months. One study did not report the follow-up period.

\section{Discussion}

This scoping review shows that, to date, there have been few individual level published alcohol interventions in Africa. Intriguingly and similar to the findings of the review on brief interventions in SSA (Karl Peltzer, 2014), most of these interventions were predominantly in one country, South Africa followed distantly by Kenya and Uganda. The existing epidemiology networks and policy efforts may explain the fact that interventions were particularly 
implemented in South Africa and Kenya (NACADA, 2018; South African Community Epidemiology Network on Drug Use (SACENDU), 2018). As such, it is also not surprising that the target populations for these alcohol interventions have been mainly people living with HIV due increased funding to carry out HIV research in SSA. Among the identified papers, only one paper reported on intervention among the students (Pengpid, Peltzer, van der Heever, \& Skaal, 2013) and one on intervention among female sex workers (L'Engle, Mwarogo, Kingola, Sinkele, \& Weiner, 2014), despite a growing body of research demonstrating that sex workers, students, youth living in the slums/informal settings, and casual labourers are high-risk populations for harmful alcohol use (Francis et al., 2014; Francis et al., 2015; Swahn et al., 2011; Swahn, Culbreth, Salazar, Kasirye, \& Seeley, 2016; Swahn et al., 2018; Swahn, Culbreth, Staton, Self-Brown, \& Kasirye, 2017).

Our review underscores that published and rigorous alcohol use interventions are limited in SSA despite the fact that alcohol consumption is common across the continent (WHO (World Health Organisation, 2018) $(3,4)$. One of the key barriers to progress with respect to alcohol interventions is likely the limited capacity for alcohol-related research and evaluation, training programs or resources devoted to alcohol use research. As such, a key priority needs to be training of clinicians and public health professionals to strengthen capacity for this work and to also engage and to facilitate collaborations across stakeholders and sectors. Within Africa, as in other regions, many non-government and community-based organizations engage in alcohol prevention and intervention efforts. Resources and expertise to implement alcohol interventions are typically limited but if provided, could dramatically increase the state of the field and save lives. 
In particular, the training and dissemination of brief interventions and motivational interviewing techniques which have been proven effective and easily scalable in low-income settings (Huis In 't Veld et al., 2012; L'Engle et al., 2014; Naar-King et al., 2008; Pengpid, Peltzer, Skaal, \& Van der Heever, 2013; Pengpid, Peltzer, van der Heever, et al., 2013) could be a window of opportunity for the future of alcohol interventions in SSA. However, stigma against alcohol use needs to be addressed more broadly as it has been identified as a key barrier to health-care providers' use of screening for alcohol use (Staton et al., 2018).

With a scoping review like this, there are several key limitations to consider when interpreting our findings regarding alcohol interventions. One of the key limitations of this review is the potential omission of ongoing interventions that have not reached a publication stage or that may have been completed but never published or those not indexed in the searched databases. It is clear that there are many non-government and community-based organizations and clinics that conduct alcohol prevention and intervention efforts, but who may not have the capacity or interest in publishing their work. As such, those efforts cannot be captured in this type of review. However, the intent of the scoping review is to gather an understanding of the types of alcohol interventions that have been implemented and where they have been conducted. Our findings show that SSA has had a few individual level alcohol interventions. In addition, these interventions were polarised in few countries (South Africa and Kenya).

\section{Conclusions}

Our review underscores that there is an urgent need to invest in alcohol interventions in SSA due to continued escalation of use fuelled by wide availability and aggressive alcohol marketing, particularly to young people (Letsela et al., 2018; Morojele et al., 2018; Obot, 
2015; Swahn et al., 2018). Alcohol reduction interventions designed for low-resource settings such as mhealth strategies and that can be scaled to larger populations will be key to protect vulnerable groups (Swahn, Braunstein, \& Kasirye, 2014). Moreover, it will be critically important to build capacity for alcohol-related research and evaluation, to provide training and resources commensurate with the scope of the problem and to more broadly address this neglected public health problem.

\section{Declarations}

Ethics approval and consent to participate:

Not applicable

Consent to publication

Not applicable

Availability of data and material

This is the review article, we have shared the search strategy.

Funding

This project did not receive any funding.

Competing interests

Authors have no competing interests.

\section{Author's contributions}

JMF, SC developed the study design, with contributions from MHS and NKM. JMF and SC carried out the systematic searching of the article's citations. JMF reviewed the articles 
citation. In addition, JMF, SC and MHS worked on a data collection tools for contacting alcohol investigators and experts. JMF and NKM performed data analysis, with contributions from MHS and SC. All authors took part in the interpretation of the data. JMF, SC, MHS and NKM drafted the article, and all authors provided critical revisions of the article for important intellectual content.

\section{Acknowledgements}

We are grateful to experts and investigators who responded to our email messages and the questionnaire posted in the online platforms. 


\section{References}

Burnhams, N. H., London, L., Laubscher, R., Nel, E., \& Parry, C. (2015). Results of a cluster randomised controlled trial to reduce risky use of alcohol, alcohol-related HIV risks and improve help-seeking behaviour among safety and security employees in the Western Cape, South Africa. Subst Abuse Treat Prev Policy, 10, 18. doi:10.1186/s13011-015-0014-5

Chaudhury, S., Brown, F. L., Kirk, C. M., Mukunzi, S., Nyirandagijimana, B., Mukandanga, J., . . . Betancourt, T. S. (2016). Exploring the potential of a family-based prevention intervention to reduce alcohol use and violence within HIV-affected families in Rwanda. AIDS Care, 28 Suppl 2, 118-129. doi:10.1080/09540121.2016.1176686

Chersich, M. F., Urban, M., Olivier, L., Davies, L. A., Chetty, C., \& Viljoen, D. (2012). Universal prevention is associated with lower prevalence of fetal alcohol spectrum disorders in Northern Cape, South Africa: a multicentre before-after study. Alcohol Alcohol, 47(1), 67-74. doi:10.1093/alcalc/agr145

Clair, V. M., V.; Musau, A.; Frank,E.; Ndetei, D. (2016). Online learning improves substance use care in Kenya: Randomized control trial results and implications. Annals of Global Health, 82(3), 319-327.

Clair, V. M., V.; Musau, A.; Frank,E.; Ndetei, D. (2017). The computer-based drug and alcohol training assessment in Kenya. Drug and Alcohol Dependence, 171, e2-e226.

de Vries, M. M., Joubert, B., Cloete, M., Roux, S., Baca, B. A., Hasken, J. M., . . May, P. A. (2015). Indicated Prevention of Fetal Alcohol Spectrum Disorders in South Africa: Effectiveness of Case Management. Int J Environ Res Public Health, 13(1), ijerph13010076. doi:10.3390/ijerph13010076

Emenyonu, N. I., Fatch, R., Muyindike, W. R., Kekibiina, A., Woolf-King, S., \& Hahn, J. A. (2017). Randomized Study of Assessment Effects on Alcohol Use by Persons With HIV in Rural Uganda. J Stud Alcohol Drugs, 78(2), 296-305.

Ferreira-Borges, C., Esser, M. B., Dias, S., Babor, T., \& Parry, C. D. (2015). Alcohol Control Policies in 46 African Countries: Opportunities for Improvement. Alcohol Alcohol, 50(4), 470-476. doi:10.1093/alcalc/agv036

Francis, J. M., Grosskurth, H., Changalucha, J., Kapiga, S. H., \& Weiss, H. A. (2014). Systematic review and meta-analysis: Prevalence of alcohol use among young people in eastern Africa. Tropical Medicine and International Health, 19(4), 476-488.

Francis, J. M., Weiss, H. A., Mshana, G., Baisley, K., Grosskurth, H., \& Kapiga, S. H. (2015). The Epidemiology of Alcohol Use and Alcohol Use Disorders among Young People in Northern Tanzania. PLoS One, 10(10), e0140041. doi:10.1371/journal.pone.0140041

Gouse, H., Magidson, J. F., Burnhams, W., Remmert, J. E., Myers, B., Joska, J. A., \& Carrico, A. W. (2016). Implementation of Cognitive-Behavioral Substance Abuse Treatment in Sub-Saharan Africa: Treatment Engagement and Abstinence at Treatment Exit. PLoS One, 11(1), e0147900. doi:10.1371/journal.pone.0147900

Huis In 't Veld, D., Skaal, L., Peltzer, K., Colebunders, R., Ndimande, J. V., \& Pengpid, S. (2012). The efficacy of a brief intervention to reduce alcohol misuse in patients with HIV in South Africa: study protocol for a randomized controlled trial. Trials, 13, 190. doi:10.1186/1745-6215-13190

Kalichman, S. C., Simbayi, L. C., Cain, D., Carey, K. B., Carey, M. P., Eaton, L., ... Mwaba, K. (2014). Randomized community-level HIV prevention intervention trial for men who drink in South African alcohol-serving venues. Eur J Public Health, 24(5), 833-839. doi:10.1093/eurpub/ckt172

Kalichman, S. C., Simbayi, L. C., Cloete, A., Clayford, M., Arnolds, W., Mxoli, M., ... Kalichman, M. O. (2009). Integrated gender-based violence and HIV Risk reduction intervention for South African men: results of a quasi-experimental field trial. Prev Sci, 10(3), 260-269. doi:10.1007/s11121-009-0129-x 
Kalichman, S. C., Simbayi, L. C., Vermaak, R., Cain, D., Smith, G., Mthebu, J., \& Jooste, S. (2008). Randomized trial of a community-based alcohol-related HIV risk-reduction intervention for men and women in Cape Town South Africa. Ann Behav Med, 36(3), 270-279. doi:10.1007/s12160-008-9067-2

L'Engle, K. L., Mwarogo, P., Kingola, N., Sinkele, W., \& Weiner, D. H. (2014). A randomized controlled trial of a brief intervention to reduce alcohol use among female sex workers in Mombasa, Kenya. J Acquir Immune Defic Syndr, 67(4), 446-453. doi:10.1097/QAl.0000000000000335

Lasebikan, V., Ola, B. A., \& Ayinde, O. O. (2017). Effectiveness of Alcohol, Smoking, and Substance Involvement Screening Test-Linked Brief Intervention on Harmful and Hazardous Alcohol Use in Nigerian Semirural Communities: A Non-Randomized Intervention Study. Front Psychiatry, 8, 50. doi:10.3389/fpsyt.2017.00050

Letsela, L., Weiner, R., Gafos, M., \& Fritz, K. (2018). Alcohol Availability, Marketing, and Sexual Health Risk Amongst Urban and Rural Youth in South Africa. AIDS Behav. doi:10.1007/s10461-0182250-y

Lynda Duffett, C. L. W. (2015). Can a motivational-interviewing-based outpatient substance abuse treatment achieve success? A theory-based evaluation. African Journal of Drug and Alcohol Studies, 14(1).

Marais, S., Jordaan, E., Viljoen, D., Olivier, L., de Waal, J., \& Poole, C. (2010). The effect of brief interventions on the drinking behaviour of pregnant women in a high-risk rural South African community: a cluster randomised trial. Early Child Development and Care, 181(4), 463-474. doi:10.1080/03004430903450392

Morojele, N. K., Lombard, C., Harker Burnhams, N., Petersen Williams, P., Nel, E., \& Parry, C. D. H. (2018). Alcohol marketing and adolescent alcohol consumption: Results from the International Alcohol Control study (South Africa). S Afr Med J, 108(9), 782-788. doi:10.7196/SAMJ.2018.v108i9.12958

Mwansa-Kambafwile, J., Rendall-Mkosi, K., Jacobs, R., Nel, E., \& London, L. (2011). Evaluation of a service provider short course for prevention of fetal alcohol syndrome. J Stud Alcohol Drugs, 72(4), 530-535.

Naar-King, S., Lam, P., Wang, B., Wright, K., Parsons, J. T., \& Frey, M. A. (2008). Brief report: maintenance of effects of motivational enhancement therapy to improve risk behaviors and HIV-related Health in a randomized controlled trial of youth living with HIV. J Pediatr Psychol, 33(4), 441-445. doi:10.1093/jpepsy/jsm087

NACADA. (2018). National Authority for the Campaign Against Alcohol and Drug Abuse (NACADA). Retrieved from http://nacada.go.ke/

Obot, I. S. (2015). Africa faces a growing threat from neo-colonial alcohol marketing. Addiction, 110(9), 1371-1372. doi:10.1111/add.13019

Parry, C. D., Morojele, N. K., Myers, B. J., Kekwaletswe, C. T., Manda, S. O., Sorsdahl, K., .. . Shuper, P. A. (2014). Efficacy of an alcohol-focused intervention for improving adherence to antiretroviral therapy (ART) and HIV treatment outcomes - a randomised controlled trial protocol. BMC Infect Dis, 14, 500. doi:10.1186/1471-2334-14-500

Peltzer, K. (2014). Brief Intervention of Alcohol Problems in Sub-Saharan Africa: A Review. Journal of Psychology in Africa, 19(3), 415-422. doi:10.1080/14330237.2009.10820310

Peltzer, K., Matseke, G., \& Azwihangwisi, M. (2008). Evaluation of alcohol screening and brief intervention in routine practice of primary care nurses in Vhembe district, South Africa. Croat Med J, 49(3), 392-401.

Pengpid, S., Peltzer, K., Skaal, L., \& Van der Heever, H. (2013). Screening and brief interventions for hazardous and harmful alcohol use among hospital outpatients in South Africa: results from a randomized controlled trial. BMC Public Health, 13, 644. doi:10.1186/1471-2458-13-644

Pengpid, S., Peltzer, K., van der Heever, H., \& Skaal, L. (2013). Screening and brief interventions for hazardous and harmful alcohol use among university students in South Africa: results from a 
randomized controlled trial. Int J Environ Res Public Health, 10(5), 2043-2057.

doi:10.3390/ijerph10052043

Rehm, J., Mathers, C., Popova, S., Thavorncharoensap, M., Teerawattananon, Y., \& Patra, J. (2009). Global burden of disease and injury and economic cost attributable to alcohol use and alcohol-use disorders. The Lancet, 373(9682), 2223-2233.

Rendall-Mkosi, K., Morojele, N., London, L., Moodley, S., Singh, C., \& Girdler-Brown, B. (2013). A randomized controlled trial of motivational interviewing to prevent risk for an alcoholexposed pregnancy in the Western Cape, South Africa. Addiction, 108(4), 725-732. doi:10.1111/add.12081

Rotheram-Borus, M. J., Tomlinson, M., Durkin, A., Baird, K., DeCelles, J., \& Swendeman, D. (2016). Feasibility of Using Soccer and Job Training to Prevent Drug Abuse and HIV. AIDS Behav, 20(9), 1841-1850. doi:10.1007/s10461-015-1262-0

Rotheram-Borus, M. J., Tomlinson, M., Roux, I. L., \& Stein, J. A. (2015). Alcohol Use, Partner Violence, and Depression: A Cluster Randomized Controlled Trial Among Urban South African Mothers Over 3 Years. Am J Prev Med, 49(5), 715-725. doi:10.1016/j.amepre.2015.05.004

South African Community Epidemiology Network on Drug Use (SACENDU). (2018). South African Community Epidemiology Network on Drug Use (SACENDU). Retrieved from http://www.mrc.ac.za/intramural-research-units/ATOD-sacendu

Staton, C. A., Vissoci, J. R. N., Wojcik, R., Hirshon, J. M., Mvungi, M., Mmbaga, B. T., \& Swahn, M. (2018). Perceived barriers by health care providers for screening and management of excessive alcohol use in an emergency department of a low-income country. Alcohol, 71, 6573. doi:10.1016/j.alcohol.2018.01.003

Swahn, M. H., Ali, B., Palmier, J., Tumwesigye, N. M., Sikazwe, G., Twa-Twa, J., \& Rogers, K. (2011). Early alcohol use and problem drinking among students in Zambia and Uganda. J Public Health Afr, 2(2), e20. doi:10.4081/jphia.2011.e20

Swahn, M. H., Braunstein, S., \& Kasirye, R. (2014). Demographic and psychosocial characteristics of mobile phone ownership and usage among youth living in the slums of Kampala, Uganda. West J Emerg Med, 15(5), 600-603. doi:10.5811/westjem.2014.4.20879

Swahn, M. H., Culbreth, R., Salazar, L. F., Kasirye, R., \& Seeley, J. (2016). Prevalence of HIV and Associated Risks of Sex Work among Youth in the Slums of Kampala. AIDS Res Treat, 2016, 5360180. doi:10.1155/2016/5360180

Swahn, M. H., Culbreth, R., Tumwesigye, N. M., Topalli, V., Wright, E., \& Kasirye, R. (2018). Problem Drinking, Alcohol-Related Violence, and Homelessness among Youth Living in the Slums of Kampala, Uganda. Int J Environ Res Public Health, 15(6). doi:10.3390/ijerph15061061

Swahn, M. H., Culbreth, R. E., Staton, C. A., Self-Brown, S. R., \& Kasirye, R. (2017). Alcohol-Related Physical Abuse of Children in the Slums of Kampala, Uganda. Int J Environ Res Public Health, 14(10). doi:10.3390/ijerph14101124

Tricco, A. C., Lillie, E., Zarin, W., O'Brien, K. K., Colquhoun, H., Levac, D., . . Straus, S. E. (2018). PRISMA Extension for Scoping Reviews (PRISMA-ScR): Checklist and Explanation. Ann Intern Med, 169(7), 467-473. doi:10.7326/M18-0850

WHO BriefIntervention Study Group. (1996). A Cross-National Trial of Brief Interventions with Heavy Drinkers. American Journal of Public Health, 86(No. 7).

World Health Organisation. ( 2018). Global status report on alcohol and health 2018. Retrieved from Geneva: http://apps.who.int/iris/bitstream/handle/10665/274603/9789241565639eng.pdf?ua=1 


\section{Figure legend}

1. Figure 1: The flow diagram (Identified citation to included papers

\section{Appendices}

1. Appendix 1: (Questionnaire for investigators and alcohol experts)

2. Appendix 2: (Search terms) 
Table 1: Description of the alcohol interventions in Africa

\begin{tabular}{|c|c|c|c|c|c|c|c|c|c|c|}
\hline Author & $\begin{array}{c}\text { Publication } \\
\text { year }\end{array}$ & Study year & Study design & Country & Sample size & Study setting & $\begin{array}{c}\text { Targeted } \\
\text { Population }\end{array}$ & $\begin{array}{c}\text { Alcohol } \\
\text { Intervention }\end{array}$ & $\begin{array}{c}\text { Study } \\
\text { maximum } \\
\text { follow up } \\
\text { time }\end{array}$ & $\begin{array}{c}\text { Primary outcome of } \\
\text { the intervention }\end{array}$ \\
\hline $\begin{array}{l}\text { L'Engle et } \\
\text { al(L'Engle et al., } \\
\text { 2014) }\end{array}$ & 2014 & 2011-2011 & $\begin{array}{l}\text { Randomized } \\
\text { clinical trial }\end{array}$ & Kenya & 818 & Community & Female sex Workers & Brief intervention & 12 months & Reduced alcohol use \\
\hline $\begin{array}{l}\text { Clair et al(Clair, } \\
\text { 2017) }\end{array}$ & 2017 & Not reported & $\begin{array}{l}\text { Randomized } \\
\text { clinical trial }\end{array}$ & Kenya & 696 & Health facility & $\begin{array}{l}\text { Health facilities, } \\
\text { health care workers }\end{array}$ & $\begin{array}{c}\text { Online training } \\
\text { on alcohol } \\
\text { interventions }\end{array}$ & 6 months & $\begin{array}{l}\text { Optimal delivery of } \\
\text { brief intervention and } \\
\text { Reduced alcohol use }\end{array}$ \\
\hline $\begin{array}{l}\text { Clair et al(Clair, } \\
\text { 2016) }\end{array}$ & 2016 & Not reported & $\begin{array}{l}\text { Randomized } \\
\text { clinical trial }\end{array}$ & Kenya & 696 & Health facility & Patients & Brief intervention & 6 months & Reduced alcohol use \\
\hline $\begin{array}{l}\text { WHO Brief } \\
\text { Intervention Study } \\
\text { Group(WHO } \\
\text { BriefIntervention } \\
\text { Study Group, } \\
\text { 1996) }^{\mathbf{1}}\end{array}$ & 1996 & Not reported & $\begin{array}{l}\text { Randomized } \\
\text { clinical trial }\end{array}$ & Kenya & 200 & $\begin{array}{l}\text { Health facility } \\
\text { and } \\
\text { community }\end{array}$ & $\begin{array}{c}\text { Patients and general } \\
\text { population }\end{array}$ & Brief intervention & 9 months & Reduced alcohol use \\
\hline $\begin{array}{l}\text { Lasebikan et } \\
\text { al(Lasebikan, }\end{array}$ & 2017 & $2010-2011$ & $\begin{array}{c}\text { Quasi } \\
\text { experimental }\end{array}$ & Nigeria & 1203 & Community & General population & $\begin{array}{l}\text { CHW delivered } \\
\text { brief intervention }\end{array}$ & 6 months & Reduced alcohol use \\
\hline
\end{tabular}




\begin{tabular}{|c|c|c|c|c|c|c|c|c|c|c|}
\hline $\begin{array}{l}\text { Ola, \& Ayinde, } \\
\text { 2017) }\end{array}$ & & & & & & & & & & \\
\hline $\begin{array}{l}\text { Chaudhury et } \\
\text { al(Chaudhury et } \\
\text { al., 2016) }\end{array}$ & 2016 & Not reported & $\begin{array}{l}\text { Randomized } \\
\text { clinical trial }\end{array}$ & Rwanda & 295 & Community & $\begin{array}{l}\text { Family with HIV } \\
\text { infected care giver }\end{array}$ & $\begin{array}{l}\text { Family support } \\
\text { intervention for } \\
\text { HIV }\end{array}$ & 9 months & Reduced alcohol use \\
\hline $\begin{array}{l}\text { Chersich et } \\
\text { al(Chersich et al., } \\
\text { 2012) }\end{array}$ & 2012 & 2003-2010 & $\begin{array}{c}\text { Quasi } \\
\text { experimental }\end{array}$ & $\begin{array}{l}\text { South } \\
\text { Africa }\end{array}$ & 809 & $\begin{array}{l}\text { Health facility } \\
\text { and } \\
\text { community }\end{array}$ & Pregnant women & $\begin{array}{l}\text { Education and } \\
\text { health promotion }\end{array}$ & 18 months & $\begin{array}{l}\text { Reduced FASD and } \\
\text { increased knowledge } \\
\text { among pregnant } \\
\text { women }\end{array}$ \\
\hline $\begin{array}{l}\text { Peltzer et al(K. } \\
\text { Peltzer, Matseke, } \\
\text { \& Azwihangwisi, } \\
\text { 2008) }\end{array}$ & 2008 & 2006-2006 & $\begin{array}{l}\text { Evaluation of } \\
\text { the } \\
\text { intervention }\end{array}$ & $\begin{array}{l}\text { South } \\
\text { Africa }\end{array}$ & 196 & Health facility & Health providers & $\begin{array}{l}\text { Training on how } \\
\text { to deliver } \\
\text { Screening and } \\
\text { Brief Intervention }\end{array}$ & 6 months & $\begin{array}{l}\text { Implementation of } \\
\text { screening and brief } \\
\text { intervention }\end{array}$ \\
\hline $\begin{array}{l}\text { Kalichman et } \\
\text { al(Kalichman et } \\
\text { al., 2008) }\end{array}$ & 2008 & 2006-2007 & $\begin{array}{l}\text { Randomized } \\
\text { clinical trial }\end{array}$ & $\begin{array}{l}\text { South } \\
\text { Africa }\end{array}$ & 353 & $\begin{array}{l}\text { Drinking } \\
\text { venue }\end{array}$ & General population & Brief intervention & 6 months & $\begin{array}{c}\text { Reduced alcohol use } \\
\text { and other risky } \\
\text { behaviours }\end{array}$ \\
\hline $\begin{array}{l}\text { Marais et } \\
\text { al(Marais et al., } \\
\text { 2010) }\end{array}$ & 2011 & 2007-2008 & $\begin{array}{c}\text { Cluster } \\
\text { randomized } \\
\text { trial }\end{array}$ & $\begin{array}{l}\text { South } \\
\text { Africa }\end{array}$ & 194 & Health facility & Pregnant women & Brief intervention & 8 weeks & Reduced alcohol use \\
\hline $\begin{array}{l}\text { Mwansa- } \\
\text { Kambafwile et } \\
\text { al(Mwansa- }\end{array}$ & 2011 & 2008-2008 & $\begin{array}{l}\text { Evaluation of } \\
\text { the } \\
\text { intervention }\end{array}$ & $\begin{array}{l}\text { South } \\
\text { Africa }\end{array}$ & 109 & Health facility & $\begin{array}{l}\text { Health care } \\
\text { providers }\end{array}$ & $\begin{array}{l}\text { Training of the } \\
\text { providers on brief }\end{array}$ & $\begin{array}{l}\text { Pre and } \\
\text { post } \\
\text { training }\end{array}$ & $\begin{array}{c}\text { Knowledge on how to } \\
\text { deliver brief }\end{array}$ \\
\hline
\end{tabular}




\begin{tabular}{|c|c|c|c|c|c|c|c|c|c|c|}
\hline $\begin{array}{l}\text { Kambafwile, } \\
\text { Rendall-Mkosi, } \\
\text { Jacobs, Nel, \& } \\
\text { London, 2011) }\end{array}$ & & & & & & & & $\begin{array}{l}\text { motivational } \\
\text { interviewing }\end{array}$ & & $\begin{array}{l}\text { motivational } \\
\text { interviewing }\end{array}$ \\
\hline $\begin{array}{l}\text { Gouse et al(Gouse } \\
\text { et al., 2016) }\end{array}$ & 2016 & $2008-2010$ & $\begin{array}{l}\text { Evaluation of } \\
\text { the program }\end{array}$ & $\begin{array}{l}\text { South } \\
\text { Africa }\end{array}$ & 986 & Health facility & Outpatients & $\begin{array}{l}\text { Standard } \\
\text { substance abuse } \\
\text { counselling using } \\
\text { matrix model }\end{array}$ & 2 years & $\begin{array}{l}\text { Urine test for markers } \\
\text { of substance use }\end{array}$ \\
\hline $\begin{array}{l}\text { de Vries et al(de } \\
\text { Vries et al., 2015) }\end{array}$ & 2015 & 2009-2011 & $\begin{array}{c}\text { Quasi } \\
\text { experimental }\end{array}$ & $\begin{array}{l}\text { South } \\
\text { Africa }\end{array}$ & 67 & Health facility & Pregnant women & $\begin{array}{l}\text { Motivational } \\
\text { interviewing }\end{array}$ & 18 months & Reduced alcohol use \\
\hline $\begin{array}{l}\text { Rotheram-Borus } \\
\text { et al(Rotheram- } \\
\text { Borus, } \\
\text { Tomlinson, } \\
\text { Roux, \& Stein, } \\
\text { 2015) }\end{array}$ & 2015 & 2009-2014 & $\begin{array}{c}\text { Cluster } \\
\text { randomized } \\
\text { trial }\end{array}$ & $\begin{array}{l}\text { South } \\
\text { Africa }\end{array}$ & 1283 & Community & Pregnant women & $\begin{array}{c}\text { Alcohol } \\
\text { counselling }\end{array}$ & 3 years & $\begin{array}{l}\text { Reduced alcohol use } \\
\text { and intimate partner } \\
\text { violence }\end{array}$ \\
\hline $\begin{array}{l}\text { Duffett et } \\
\text { al(Lynda Duffett, } \\
\text { 2015) }\end{array}$ & 2016 & 2011-2012 & $\begin{array}{l}\text { Evaluation of } \\
\text { the program }\end{array}$ & $\begin{array}{l}\text { South } \\
\text { Africa }\end{array}$ & 142 & Health facility & Outpatients & $\begin{array}{l}\text { Motivational } \\
\text { interviewing }\end{array}$ & 10 weeks & $\begin{array}{c}\text { Substance use scores } \\
\text { and abstinence }\end{array}$ \\
\hline $\begin{array}{l}\text { Burnhams et } \\
\text { al(Burnhams, } \\
\text { London, }\end{array}$ & 2015 & 2011-2012 & $\begin{array}{c}\text { Cluster } \\
\text { randomized } \\
\text { trial }\end{array}$ & $\begin{array}{l}\text { South } \\
\text { Africa }\end{array}$ & 325 & Community & Employees & $\begin{array}{c}\text { Alcohol } \\
\text { counselling }\end{array}$ & 3 months & $\begin{array}{c}\text { Reduced current } \\
\text { alcohol use and binge } \\
\text { drinking }\end{array}$ \\
\hline
\end{tabular}




\begin{tabular}{|c|c|c|c|c|c|c|c|c|c|c|}
\hline $\begin{array}{l}\text { Laubscher, Nel, } \\
\text { \& Parry, 2015) }\end{array}$ & & & & & & & & & & \\
\hline $\begin{array}{l}\text { Pengpid et } \\
\text { al(Pengpid, } \\
\text { Peltzer, van der } \\
\text { Heever, et al., } \\
\text { 2013) }\end{array}$ & 2013 & 2011-2012 & $\begin{array}{l}\text { Randomized } \\
\text { clinical trial }\end{array}$ & $\begin{array}{l}\text { South } \\
\text { Africa }\end{array}$ & 152 & University & University students & Brief intervention & 12 months & $\begin{array}{l}\text { Reduced alcohol and } \\
\text { other substance use } \\
\text { and depression and } \\
\text { post-traumatic stress } \\
\text { disorders }\end{array}$ \\
\hline $\begin{array}{l}\text { Huis In 't Veld et } \\
\text { al(Huis In 't Veld } \\
\text { et al., 2012) }\end{array}$ & 2012 & 2012- & $\begin{array}{l}\text { Randomized } \\
\text { clinical trial } \\
\text { protocol }\end{array}$ & $\begin{array}{l}\text { South } \\
\text { Africa }\end{array}$ & 240 & Health facility & HIV patients & Brief intervention & 12 months & Reduced alcohol use \\
\hline $\begin{array}{l}\text { Parry et al(Parry } \\
\text { et al., 2014) }\end{array}$ & 2014 & 2015- & $\begin{array}{l}\text { Randomized } \\
\text { clinical trial } \\
\text { protocol }\end{array}$ & $\begin{array}{l}\text { South } \\
\text { Africa }\end{array}$ & 600 & Health facility & HIV patients & $\begin{array}{l}\text { Motivational } \\
\text { interviewing and } \\
\text { Problem solving } \\
\text { therapy }\end{array}$ & 12 months & $\begin{array}{l}\text { Reduced alcohol use } \\
\text { and improvement of } \\
\text { HIV treatment } \\
\text { outcomes }\end{array}$ \\
\hline $\begin{array}{l}\text { Rotheram-Borus } \\
\text { et al(Rotheram- } \\
\text { Borus et al., } \\
\text { 2016) }\end{array}$ & 2016 & Not reported & $\begin{array}{c}\text { Cluster } \\
\text { randomized } \\
\text { trial }\end{array}$ & $\begin{array}{l}\text { South } \\
\text { Africa }\end{array}$ & 142 & Community & Unemployed men & $\begin{array}{c}\text { Alcohol } \\
\text { counselling }\end{array}$ & 24 weeks & Reduced alcohol use \\
\hline $\begin{array}{l}\text { Kalichman et } \\
\text { al(Kalichman et } \\
\text { al., 2009) }\end{array}$ & 2009 & Not reported & $\begin{array}{c}\text { Evaluation of } \\
\text { the } \\
\text { intervention }\end{array}$ & $\begin{array}{l}\text { South } \\
\text { Africa }\end{array}$ & 475 & Community & $\begin{array}{c}\text { Men in general } \\
\text { population }\end{array}$ & Brief intervention & 6 months & $\begin{array}{l}\text { Gender based violence, } \\
\text { Reduced alcohol use }\end{array}$ \\
\hline
\end{tabular}




\begin{tabular}{|c|c|c|c|c|c|c|c|c|c|c|}
\hline $\begin{array}{l}\text { Pengpid et } \\
\text { al(Pengpid, } \\
\text { Peltzer, Skaal, et } \\
\text { al., 2013) }\end{array}$ & 2013 & 2011-2012 & $\begin{array}{l}\text { Randomized } \\
\text { clinical trial }\end{array}$ & $\begin{array}{l}\text { South } \\
\text { Africa }\end{array}$ & 392 & Health facility & Outpatients & Brief intervention & 12 months & Reduced alcohol use \\
\hline $\begin{array}{l}\text { Kalichman et } \\
\text { al(Kalichman et } \\
\text { al., 2014) }\end{array}$ & 2014 & Not reported & $\begin{array}{c}\text { Cluster } \\
\text { randomized } \\
\text { trial }\end{array}$ & $\begin{array}{l}\text { South } \\
\text { Africa }\end{array}$ & 2487 & $\begin{array}{l}\text { Drinking } \\
\text { venue }\end{array}$ & General population & $\begin{array}{c}\text { Alcohol } \\
\text { counselling }\end{array}$ & 12 months & Reduced alcohol use \\
\hline $\begin{array}{l}\text { Rendall-Mkosi et } \\
\text { al(Rendall-Mkosi } \\
\text { et al., 2013) }\end{array}$ & 2013 & $2007-2008$ & $\begin{array}{l}\text { Randomized } \\
\text { Clinical trial }\end{array}$ & $\begin{array}{l}\text { South } \\
\text { Africa }\end{array}$ & 196 & $\begin{array}{l}\text { Health facility } \\
\text { and } \\
\text { community }\end{array}$ & $\begin{array}{l}\text { Women of child- } \\
\text { bearing age }\end{array}$ & $\begin{array}{l}\text { Motivational } \\
\text { interviewing }\end{array}$ & 12 months & $\begin{array}{c}\text { Alcohol exposed } \\
\text { pregnancy }\end{array}$ \\
\hline $\begin{array}{l}\text { EmenyonuNneka } \\
\text { et al(Emenyonu } \\
\text { et al., 2017) }\end{array}$ & 2017 & 2011-2013 & $\begin{array}{l}\text { Randomized } \\
\text { clinical trial }\end{array}$ & Uganda & 373 & Health facility & HIV patients & $\begin{array}{c}\text { alcohol } \\
\text { assessments }\end{array}$ & 6 months & Reduced alcohol use \\
\hline Wandera et al & 2017 & 2013-2014 & $\begin{array}{l}\text { Randomized } \\
\text { clinical trial }\end{array}$ & Uganda & 337 & Health facility & HIV patients & $\begin{array}{c}\text { Brief } \\
\text { motivational } \\
\text { interviewing }\end{array}$ & 6 months & Reduced alcohol use \\
\hline $\begin{array}{l}\text { WHO Brief } \\
\text { Intervention Study } \\
\text { Group(WHO } \\
\text { BriefIntervention } \\
\text { Study Group, } \\
\text { 1996) }^{\mathbf{1}}\end{array}$ & 1996 & Not reported & $\begin{array}{l}\text { Randomized } \\
\text { clinical trial }\end{array}$ & Zimbabwe & 129 & $\begin{array}{l}\text { Health facility } \\
\text { and } \\
\text { community }\end{array}$ & $\begin{array}{c}\text { Patients and general } \\
\text { population }\end{array}$ & Brief intervention & 9 months & Reduced alcohol use \\
\hline
\end{tabular}


${ }^{1}$ Multi countries study 
Appendix 1 (Questionnaire for investigators and alcohol experts)

\begin{tabular}{|c|c|c|c|}
\hline & \multicolumn{3}{|c|}{ Review of the alcohol interventions in Sub Saharan Africa } \\
\hline & Variables & Description of the variable & Response \\
\hline 1 & Names of the investigators & $\begin{array}{l}\text { Names of the key investigators( } \\
1 \text { and last name e.g,Joel } \\
\text { Francis) }\end{array}$ & \\
\hline 2 & $\begin{array}{l}\text { Name of the organisations implementing the } \\
\text { intervention }\end{array}$ & Names of the organisations & \\
\hline 3 & Type of the organisation & $\begin{array}{l}\text { 1. Government 2. Private/Non } \\
\text { for profit 3. Both(If multiple } \\
\text { organisation) }\end{array}$ & \\
\hline 4 & Organisations local/international & $\begin{array}{l}\text { 1. Local (in country) } 2 . \\
\text { International 3. Both(Multiple } \\
\text { organisation) }\end{array}$ & \\
\hline 5 & Funding source & Name of the donor & \\
\hline 6 & Implemented in multiple countries & 1. Yes 2. No & \\
\hline 7 & Name/s of the country/ies & $\begin{array}{l}\text { Names of the countries } \\
\text { implementing the intervention }\end{array}$ & \\
\hline 8 & Current and previous name of the intervention & $\begin{array}{l}\text { Is the intervention based or } \\
\text { modified from an intervention } \\
\text { with a different name }\end{array}$ & \\
\hline 9 & Scope of the intervention & $\begin{array}{l}\text { Is the intervention focused } \\
\text { mostly on alcohol or part of a } \\
\text { broader intervention targeting } \\
\text { a range of topics }\end{array}$ & \\
\hline 10 & Type of intervention & $\begin{array}{l}\text { 1. Population level (e.g. policy } \\
\text { change) 2. Community level } \\
\text { (e.g. school based intervention) } \\
\text { 3. Individual level (non clinical) } \\
\text { 4. Individual level (clinical) } 5 . \\
\text { Other please specify }\end{array}$ & \\
\hline 11 & Design of the intervention & $\begin{array}{l}\text { 1. Experimental (Cluster } \\
\text { randomized trial) } 2 . \\
\text { Experimental (Randomized } \\
\text { control trial) 3. Quasi- } \\
\text { experimental 4. Other please } \\
\text { specify }\end{array}$ & \\
\hline 12 & Target population & $\begin{array}{l}\text { Please specify in as much detail } \\
\text { as possible age group, gender, } \\
\text { particular group e.g. pregnant } \\
\text { mothers, alcohol dependent } \\
\text { patients) }\end{array}$ & \\
\hline 13 & Female focus & 1. Yes 2. No & \\
\hline 14 & Male focus & 1. Yes 2. No & \\
\hline 15 & Date of the intervention commencement & Month, year e.g, March, 2016 & \\
\hline 16 & Date/tentative of the end of intervention & Month, year e.g, March, 2017 & \\
\hline 17 & Description of the intervention/s & $\begin{array}{l}\text { detail the intervention ( type of } \\
\text { intervention, dosage, follow up) }\end{array}$ & \\
\hline
\end{tabular}




\begin{tabular}{|c|c|c|}
\hline 18 & Aims of the intervention & $\begin{array}{l}\text { Eg. To determine the effect of } \\
\text { brief intervention on alcohol } \\
\text { consumption. }\end{array}$ \\
\hline 19 & Measured Outcomes & $\begin{array}{l}\text { Eg. Decreased alcohol } \\
\text { consumption }\end{array}$ \\
\hline 20 & Measurement of alcohol use & $\begin{array}{l}\text { Please provide details of how } \\
\text { alcohol use measured at the } \\
\text { start and end of the study }\end{array}$ \\
\hline 21 & Project report available & 1. Yes 2. No \\
\hline 22 & Is the report published & 1. Yes 2. No \\
\hline 23 & Name of the Journal & 1. Yes 2. No \\
\hline 24 & Date published & Month, year e.g, March, 2016 \\
\hline 25 & Can you share the unpublished report & 1. Yes 2. No \\
\hline 26 & $\begin{array}{l}\text { Can we contact you for further details of your } \\
\text { project }\end{array}$ & 1. Yes 2. No \\
\hline 27 & Contact details & email, phone number \\
\hline
\end{tabular}




\section{Appendix 2(Search terms)}

Alcohol use

Alcohol OR Alcohol consumption

AND

Interventions

(Alcohol reduction OR Brief intervention OR Early intervention OR Minimal intervention OR Alcohol therapy OR Harm reduction OR Screening OR Counseling OR Controlled drinking OR Brief counseling OR Physician based intervention OR General practitioner intervention OR Secondary prevention OR General practitioner's advice OR Brief physician-delivered counseling OR Brief nurse-delivered counseling OR Identification OR Intervention)

AND

Africa Search terms

Africa[Mesh] OR "Africa South of the Sahara"[Mesh] OR "sub-Saharan Africa"[All Fields] OR “Africa”[All Fields] OR “African"[All Fields] OR “Angola"[All Fields] OR "Benin"[All Fields] OR "Botswana"[All Fields] OR "Burkina Faso"[All Fields] OR "Burundi"[All Fields] OR “Cameroon"[All Fields] OR “Cape Verde"[All Fields] OR “Central African Republic"[All Fields] OR "Chad"[All Fields] OR "Comoros" "[All Fields] OR "Congo"[All Fields] OR "CongoBrazzaville"[All Fields] OR "Republic of Congo"[All Fields] OR "Democratic Republic of the Congo"[All Fields] OR “Djibouti"[All Fields] OR “Eritrea"[All Fields] OR “Ethiopia”[All Fields] OR “Equatorial Guinea"[All Fields] OR “Gabon"[All Fields] OR “Gambia”[All Fields] OR “Ghana”[All Fields] OR “Guinea"[All Fields] OR “Guinea Bissau"[All Fields] OR “Ivory Coast”[All Fields] OR "Cote d'Ivoire"[All Fields] OR "Kenya"[All Fields] OR "Lesotho"[All Fields] OR “Liberia”[All Fields] OR “Malawi”[All Fields] OR “Mali”[All Fields] OR “Mozambique”[All Fields] 
OR “Madagascar"[All Fields] OR "Mauritania"[All Fields] OR “Namibia”[All Fields] OR “Niger"[All Fields] OR “Nigeria"[All Fields] OR “Rwanda"[All Fields] "Senegal”[All Fields] OR "Sierra Leone"[All Fields] OR "Seychelles" [All Fields] OR "Somalia"[All Fields] OR "South Africa"[All Fields] OR "Sudan" [All Fields] OR "South Sudan" [All Fields] OR "Swaziland"[All Fields] OR "Tanzania"[All Fields] OR "Togo"[All Fields] OR "Uganda"[All Fields] OR "Zambia”[All Fields] OR "Zimbabwe"[All Fields]. 